\title{
Transition Dates from Earlywood to Latewood and Early Phloem to Late Phloem in Norway Spruce
}

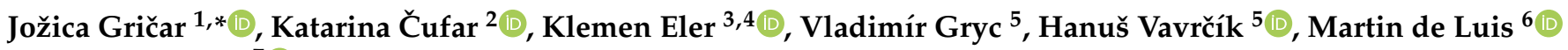 \\ and Peter Prislan ${ }^{7}$ (D)
}

check for

updates

Citation: Gričar, J.; Čufar, K.; Eler, K.; Gryc, V.; Vavrčík, H.; de Luis, M.; Prislan, P. Transition Dates from Earlywood to Latewood and Early Phloem to Late Phloem in Norway Spruce. Forests 2021, 12, 331. https://doi.org/10.3390/f12030331

Academic Editors: Celia

M. Rodriguez-Dominguez and Sergio Rossi

Received: 13 February 2021

Accepted: 8 March 2021

Published: 11 March 2021

Publisher's Note: MDPI stays neutral with regard to jurisdictional claims in published maps and institutional affiliations.

Copyright: (c) 2021 by the authors. Licensee MDPI, Basel, Switzerland. This article is an open access article distributed under the terms and conditions of the Creative Commons Attribution (CC BY) license (https:/ / creativecommons.org/licenses/by/ $4.0 /)$.
1 Department of Forest Yield and Silviculture, Slovenian Forestry Institute, 1000 Ljubljana, Slovenia

2 Department of Wood Science and Technology, Biotechnical Faculty, University of Ljubljana, 1000 Ljubljana, Slovenia; katarina.cufar@bf.uni-lj.si

3 Department of Agronomy, Biotechnical Faculty, University of Ljubljana, 1000 Ljubljana, Slovenia; klemen.eler@bf.uni-lj.si

4 Department of Forest Ecology, Slovenian Forestry Institute, 1000 Ljubljana, Slovenia

5 Department of Wood Science and Technology, Faculty of Forestry and Wood Technology, Mendel University in Brno, 61300 Brno, Czech Republic; vladimir.gryc@mendelu.cz (V.G.); xvavrcik@mendelu.cz (H.V.)

6 Department Geografía y O.T., University of Zaragoza, 50009 Zaragoza, Spain; mdla@unizar.es

7 Department of Forest Techniques and Economy, Slovenian Forestry Institute, 1000 Ljubljana, Slovenia; peter.prislan@gozdis.si

* Correspondence: jozica.gricar@gozdis.si

\begin{abstract}
Climate change will affect radial growth patterns of trees, which will result in different forest productivity, wood properties, and timber quality. While many studies have been published on xylem phenology and anatomy lately, little is known about the phenology of earlywood and latewood formation, also in relation to cambial phenology. Even less information is available for phloem. Here, we examined year-to-year variability of the transition dates from earlywood to latewood and from early phloem to late phloem in Norway spruce (Picea abies) from three temperate sites, two in Slovenia and one in the Czech Republic. Data on xylem and phloem formation were collected during 2009-2011. Sensitivity analysis was performed to determine the specific contribution of growth rate and duration on wood and phloem production, separately for early and late formed parts. We found significant differences in the transition date from earlywood to latewood between the selected sites, but not between growth seasons in trees from the same site. It occurred in the first week of July at PAN and MEN and more than two weeks later at RAJ. The duration of earlywood formation was longer than that of latewood formation; from 31.4 days at PAN to 61.3 days at RAJ. In phloem, we found differences in transition date from early phloem to late phloem also between the analysed growth seasons; from 2.5 weeks at PAN to 4 weeks at RAJ Compared to the transition from earlywood to latewood the transition from early phloem to late phloem occurred 25-64 days earlier. There was no significant relationship between the onset of cambial cell production and the transition dates. The findings are important to better understand the inter-annual variability of these phenological events in spruce from three contrasting temperate sites, and how it is reflected in xylem and phloem anatomy.
\end{abstract}

Keywords: Picea abies; xylem formation; phloem formation; cambium; tracheid; sieve cell; conifer; temperate environment

\section{Introduction}

Global warming is expected to shift phenological phases of trees and thereby lengthen the growing season. Even small increases in the duration of xylogenesis could correspond to a substantial increase in xylem width because of non-linear relationships between cambial phenology and rate of cell production [1,2]. In conifers from temperate forests, for example, the rate of cell division was found to explain most of the variability in cell 
production [3,4]. Increment width is thus affected by both the duration and rate of cambial cell production, but their influence on the width may vary depending on tree species, tree age and vitality, tree part, site conditions, etc. $[3,5,6]$. Since ring width is tightly connected with wood structure in conifers, changes in radial growth patterns in the future will affect forest productivity, wood properties, and timber quality [7].

Novel image processing and analysis systems have facilitated analysis of xylem morphological features (e.g., lumen size, cell wall thickness) [8]. Using this approach, it is possible to elucidate how various environmental factors impact on wood formation processes, which result in different wood anatomy [9]. Since wood structure defines its hydraulic and mechanical properties, it directly affects tree performance (growth and survival) [10]. It has been shown that the same tree species growing in different environments can adjust the structure of vascular tissues to some extent to local conditions, indicating their plasticity of radial growth for optimal tree functioning [11-13]. These data may be critically important in evaluating the range of plasticity in species under different environmental conditions as a first step in predicting their responses to future climatic scenarios [12]. While numerous papers have recently been published on xylem phenology and anatomy, little is known regarding year-to-year variability in transition date from earlywood to latewood in relation to their widths [14]. In terms of tree functioning, earlywood and latewood proportions are important, since large and thin-walled earlywood tracheids, produced at the beginning of the growing season, are more efficient in transporting water, but are also more vulnerable to cavitation. Narrow but thick-walled latewood tracheids, formed in the second part of the growing season, provide mechanical support [15]. Even less is known about phloem phenology and transition from early phloem to late phloem, tissue parts with different main roles in a tree [16].

Previous studies have shown that cambial phenology in Norway spruce (Picea abies (L.) H. Karst.) differs among three temperate forest sites with different climatic conditions, but it is quite stable over years in trees from the same site. Furthermore, the timing of the onset of cambial production of xylem and phloem cells proved to be synchronous, whereas the duration and dynamics of xylem and phloem formation differed [17]. In addition, the structure of earlywood and early phloem was more stable compared to latewood and late phloem [18]. The radial growth and anatomy of xylem and phloem increments were found to depend on climatic factors, although compensatory mechanisms exist to mitigate the effect of environmental signals [19]. However, large variability in increments and also xylem and phloem anatomy in trees growing under different environmental conditions confirm the plastic response of secondary growth [18]. Here, we examined year-to-year variability of the transition dates from earlywood to latewood and from early phloem to late phloem and how this variability is related to increment width and structure. For this purpose, we used wood and phloem formation data of Norway spruce from three temperate sites, two in Slovenia and one in the Czech Republic, collected during 20092011. Weather conditions at the selected sites varied, but were within the temperature and precipitation ranges that are optimal for growth in most spruce forests. We assessed the sensitivity of spruce to different growing conditions and looked for similarities in the selected phenological events in xylem and phloem. Sensitivity analysis was performed to determine the specific contribution of growth rate and duration on wood and phloem production, separately for early and late formed parts. Based on the previous findings, we raise the hypothesis that that the transition dates are more site-specific traits and vary less between growth seasons, especially in the case of phloem (H1). In the second hypothesis (H2), we assumed that transition dates were closely related to the onset of cambial cell production.

\section{Materials and Methods}

\subsection{Study Sites}

The study was carried out at three forest sites with different altitudes and latitudes: two in Slovenia and one in the Czech Republic. In Slovenia, sampling was performed at 
two uneven-aged mixed forest stands differing in altitude. The low elevation site, Panška reka (PAN), is located near Ljubljana and is classified as Hacquetio-fagetum typicum forest type (dolomite rock type), in which Fagus sylvatica L., Acer pseudoplatanus L., and Picea abies (L.) H. Karst prevail (Table 1). The high elevation site, Menina planina (MEN), is on a pre-Alpine Karst plateau in the Kamnik-Savinja Alps and is classified as Abieti fagetum prealpinum typicum forest type (limestone rock type), with F. sylvatica, P. abies, and Abies alba Mill. being the dominant species. The site in the Czech Republic, Rájec-Němčice (RAJ), is located north of Němčice, ca. $400 \mathrm{~km}$ from the Slovenian sites. The site is classified as Abieto-Fagetum mesotrophicum with Oxalis acetosella L. (acid granodiorite rock type). It is spruce monoculture (the first generation after mixed forest) [20].

Table 1. Study site and characteristics of Picea abies trees. Temperature $(\mathrm{T})$ and precipitation $(\mathrm{P})$ data are for the period 1901-2011. DBH—diameter at breast height.

\begin{tabular}{|c|c|c|c|c|c|c|c|c|c|c|}
\hline Site ID & Country & Latitude & Longitude & $\begin{array}{l}\text { Altitude } \\
\text { (m a.s.1.) }\end{array}$ & $\begin{array}{c}\text { Mean } \\
\text { Annual T } \\
\left({ }^{\circ} \mathrm{C}\right)\end{array}$ & $\begin{array}{c}\text { Mean } \\
\text { annual P } \\
(\mathrm{mm})\end{array}$ & $\begin{array}{c}\text { Tree Age } \\
\text { (year) }\end{array}$ & $\begin{array}{l}\text { Tree } \\
\text { DBH } \\
(\mathrm{cm})\end{array}$ & $\begin{array}{c}\text { Tree } \\
\text { Height } \\
\text { (m) }\end{array}$ & $\begin{array}{c}\text { Duration of } \\
\text { Cambial Cell } \\
\text { Production } \\
\text { (days) }\end{array}$ \\
\hline PAN & SI & $46^{\circ} 00^{\prime} \mathrm{N}$ & $14^{\circ} 40^{\prime} \mathrm{E}$ & 400 & 11.4 & 1400 & $68 \pm 8$ & $36 \pm 5$ & $30 \pm 5$ & $126 \pm 15$ \\
\hline MEN & SI & $46^{\circ} 16^{\prime} \mathrm{N}$ & $14^{\circ} 48^{\prime} \mathrm{E}$ & 1200 & 7.6 & 1670 & $102 \pm 31$ & $37 \pm 12$ & $25 \pm 1$ & $95 \pm 15$ \\
\hline RAJ & $\mathrm{CZ}$ & $49^{\circ} 29^{\prime} \mathrm{N}$ & $16^{\circ} 43^{\prime} \mathrm{E}$ & 650 & 8.1 & 630 & $88 \pm 4$ & $34 \pm 2$ & $32 \pm 2$ & $126 \pm 24$ \\
\hline
\end{tabular}

In Slovenia, daily weather data for the low elevation site PAN were obtained from the nearby Ljubljana weather station (Ljubljana-Bežigrad $46^{\circ} 3^{\prime} \mathrm{N}, 14^{\circ} 30^{\prime} \mathrm{E}, 299 \mathrm{~m}$ a.s.l.) of the Environmental Agency of the Republic of Slovenia. At the high elevation site MEN, a Davis ${ }^{\circledR}$ weather station was installed to measure air temperature and precipitation at hourly intervals. It was placed in the vicinity of the test trees in a small forest clearing, approximately two meters above the ground. The weather station tower at the RAJ site was located directly in the middle of the research plot for measuring air temperature (ModuLog datalogger, EMS Brno, Czech Republic). Precipitation (open space) was taken from permanently open sampling collectors in five repetitions. All weather measurements were provided by the Department of Forest Ecology, Mendel University in Brno. Average air temperature and the sums of precipitation were calculated for every week of the year. The general features of climatic regime at the three study sites are presented in Table 1.

\subsection{Tree Selection and Sample Preparation}

At each site, six dominant or co-dominant, healthy Norway spruce (Picea abies (L.) H. Karst) trees were selected. Tree characteristics are presented in Table 1. Micro-cores (1.8 $\mathrm{mm}$ in diameter) were collected at 6-8-day intervals from mid-March until mid-October in 2009, 2010, and 2011, using a Trephor tool [21]. In the two Slovenian sites (PAN and MEN), sampling was carried out on the same day, while in the Czech Republic (RAJ) it could differ by 1-2 days. The samples were collected on stems at 1.1-1.7 $\mathrm{m}$ above the ground following a spiral pattern. To avoid wound effects, adjacent sampling locations were 5-10 cm apart. Each micro-core contained inner phloem, cambial region and at least the two youngest xylem increments. The protocol of permanent cross-section preparation for histometrical analysis is described in detail in [17]. In short, the samples were cut with a rotary microtome and stained with a water solution of safranine/astra blue and embedded in Euparal. Observations and measurements of xylem and phloem developing tissues were performed with a light microscope and image analysis system.

\subsection{Phenology and Dynamics of Formation of Xylem and Phloem Tissues}

The onset and cessation of cambial cell production and maximum rate of xylem and phloem cell production were determined and defined as explained in [17]. Generalized additive models (GAMs) were used to model the seasonal dynamics of xylem and phloem growth ring formation expressed in number of cells [14,22]. To fit GAMs, the package mgcv [23] was used within R statistical software [24]. 
The models were used to evaluate the duration of the cell enlargement period ( $\mathrm{dE}$ ) and rate of cell production (rm) for earlywood and latewood, as well as for early phloem and late phloem formation. To calculate the transition dates from earlywood to latewood for each tree at a specific site and year, we used tracheidograms [18] and the Gompertz/GAM function [17]. Tracheidograms (representing the variation in cell radial dimension and wall thickness within a growth ring) were prepared by analyzing fully developed xylem increments in the samples taken at the end of the growing season-i.e., at the end of September/beginning of October [18]. Earlywood and latewood tracheids where distinguished based on Mork's index, i.e., latewood tracheids were characterised by lumen diameter smaller than twice the cell wall thickness [15]. This approach was selected since this criterion cannot be applied on developing cells. The transition dates from earlywood to latewood $(t)$ were calculated based on GAMs.

The duration of earlywood and latewood formation can be assessed in terms of cambial cell production, i.e., the period in which the cambium produced earlywood or latewood cells. Alternatively, the completion of the differentiation process can be included in the period of formation of the two tissues. Earlywood and latewood formation thus overlap for a while; the differentiation of earlywood cell walls continues when cambial production of latewood cells is already occurring. In this paper, the period of earlywood and latewood formation was related to the cambial cell production period. The duration of earlywood production was calculated as the difference between the time when the first enlarging earlywood cells (actual observation) were observed and the time when the last earlywood cell was formed (calculated based on GAMs). The duration of latewood formation was determined as the period from when the first differentiating latewood cell was calculated based on GAMs to the date when no enlarging cells were observed at the end of the growing season (actual observation). The transition date from early phloem to late phloem was determined when the first axial parenchyma cells appeared [25].

\subsection{Data Analyses}

Differences between years and sites in the transition from early to late wood and phloem increments, as well as the duration of early and late wood/phloem formation were determined with one-way repeated measurements ANOVA using the ez package within the R statistical environment [24], in which 'site' was the treatment factor and 'year of growth' was the repeated measurement. Normality of distribution and homogeneity of variance were verified using the Shapiro-Wilk W test and Levene's test, respectively [26].

Sensitivity analysis was performed for wood and phloem growth rings and their early and late parts to determine the contribution of duration and growth rates to cell production in the specific parts of wood, and phloem increments [3]. First, the total number of wood $\left(n_{X C}\right)$ and phloem $\left(n_{P C}\right)$ increments and the number of cells in the early $\left(n_{E X C}, n_{E P C}\right)$ and late $\left(n_{L X C}, n_{L P C}\right)$ parts were modeled as a function of growth rate $\left(r_{m}\right)$ and duration of cell production $\left(d_{E}\right)$. Secondly, the impact of relative variation of the input variables, according to their standard deviations, on the results of the model was evaluated.

\section{Results}

\subsection{Transition Dates of Earlywood to Latewood and Early Phloem to Late Phloem}

In a previous study, we found that the duration of cambial cell production period was the longest at PAN and the most variable at RAJ (PAN: $138.4 \pm 14.3$ days; MEN: $109.9 \pm 16.3$ days; RAJ: $122.5 \pm 20.1$ days) [17]. In terms of increment widths, the phloem rings followed the elevational gradient, i.e., widths were widest at the lowest and narrowest at the highest elevation, whereas this pattern was not so clear in the xylem rings (Figure 1). At PAN, the xylem widths were in all cases the widest, while at MEN and RAJ the difference in xylem widths depended on the year. In 2009, the xylem-ring widths were $44.8 \%$ wider at RAJ than at MEN. In 2010 and 2011, it was just the opposite, the xylem increments were $20 \%$ and $21.4 \%$, respectively, wider at MEN than at RAJ. 


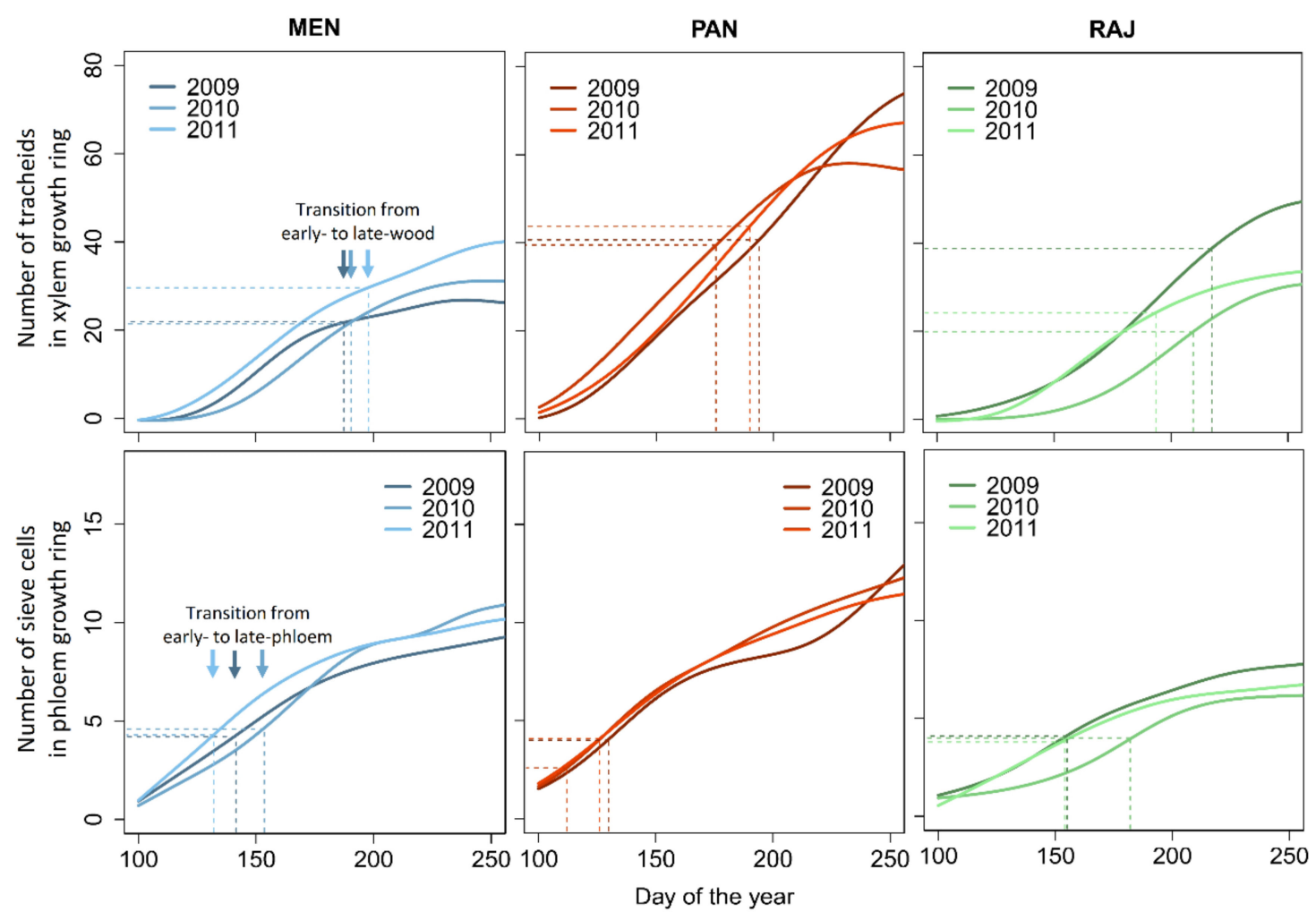

Figure 1. Inter-annual dynamics of wood and phloem growth ring formation represented by generalized additive models (GAMs) fitted to weekly wood and phloem increments in Norway spruce at MEN, PAN, and RAJ. Horizontal and vertical dashed lines indicate the number of cells and the average date of the transition from earlywood to latewood and early to late phloem in particular year.

The transition from earlywood to latewood occurred in the first week of July at PAN and MEN and more than two weeks later at RAJ (i.e., second half of July) (Tables 2 and 3). At all sites, the differences in the transition dates were not significant between growth seasons, although at RAJ the transition occurred almost three weeks later in 2009 than in 2011. In all cases, the duration of earlywood formation was longer than that of latewood formation; from 31.4 days at PAN to 61.3 days at RAJ. It also resulted in a higher share of earlywood; from $65.7 \%$ at PAN to $77.3 \%$ at MEN. In addition, the period of maximum cell production occurred at all sites during the period of earlywood formation.

The transition date from early phloem to late phloem, as determined by the presence of the first axial parenchyma cells, differed between the three sites; it occurred earliest at PAN (end of April/beginning of May) and latest at RAJ (mid or end June) (Tables 2 and 3). In addition, differences in the transition date existed between growth seasons at each site; from 2.5 weeks at PAN to 4 weeks at RAJ. Compared to the transition from earlywood to latewood the transition from early phloem to late phloem occurred 25-64 days earlier. The highest year-to-year variations in the transition date from early phloem to late phloem were found at RAJ (mean: $42.57 \pm 19.69$ days). At the Slovenian sites, MEN and PAN, the duration of early phloem formation was 57-94 days shorter compared to late phloem formation. The duration of early and late phloem formation was positively correlated to the duration of cambial activity (early phloem $r=0.66$; late phloem $r=0.95$ ). At MEN and PAN, late phloem was on average $56.0 \%$ and $66.3 \%$ wider than early phloem. At RAJ, the phloem increment was narrowest and composed, on average, of less than eight cell layers in total, with fewer than four late phloem cell layers. In this case, the duration of early and late phloem formation was comparable. In some years, such as in 2010, the period of early phloem production was on average 27 days longer, while in 2009 it was 24 days shorter than that of late phloem. Consequently, early phloem was narrower in 2009 (by 20\%) and wider in 2010 and 2011 (by 42\%) compared to late phloem. The peak of phloem formation 
preceded wood formation by 3-30 days; it occurred in the second half of May (Figure 1). Generally, the peak was related to the ring widths; in phloem rings that contained fewer than 10 cell layers, it occurred in the period of early phloem formation and in the rings wider than 10 cells it occurred in the period of late phloem formation.

Table 2. Days of transition from earlywood to latewood and early phloem to late phloem for Norway spruce at MEN, PAN, and RAJ in 2009-2011. DOY-day of the year.

\begin{tabular}{|c|c|c|c|c|c|}
\hline \multirow{2}{*}{ Study site } & \multirow{2}{*}{ Year } & \multicolumn{2}{|c|}{$\begin{array}{l}\text { Transition from Earlywood to Latewood } \\
\text { (DOY) }\end{array}$} & \multicolumn{2}{|c|}{$\begin{array}{l}\text { Transition from Early Phloem to Late Phloem } \\
\text { (DOY) }\end{array}$} \\
\hline & & $\begin{array}{c}\text { Mean } \pm \text { Standard } \\
\text { Deviation }\end{array}$ & $\begin{array}{c}\text { Relative Variability } \\
(\%)\end{array}$ & $\begin{array}{l}\text { Mean } \pm \text { Standard } \\
\text { Deviation }\end{array}$ & $\begin{array}{c}\text { Relative Variability } \\
(\%)\end{array}$ \\
\hline \multirow[t]{3}{*}{ MEN } & 2009 & $187.7 \pm 19.6$ & 10.4 & $141.3 \pm 4.5$ & 3.2 \\
\hline & 2010 & $197.9 \pm 9.3$ & 4.7 & $153.4 \pm 3.6$ & 2.3 \\
\hline & 2011 & $190.8 \pm 19.0$ & 10.0 & $131.8 \pm 5.3$ & 4.0 \\
\hline \multirow[t]{3}{*}{ PAN } & 2009 & $194.0 \pm 23.5$ & 12.1 & $129.8 \pm 2.9$ & 2.2 \\
\hline & 2010 & $175.7 \pm 16.9$ & 9.6 & $111.7 \pm 5.4$ & 4.8 \\
\hline & 2011 & $190.0 \pm 25.0$ & 13.2 & $126.0 \pm 3.3$ & 2.6 \\
\hline \multirow[t]{3}{*}{ RAJ } & 2009 & $217.5 \pm 13.4$ & 6.2 & $155.0 \pm 16.9$ & 10.9 \\
\hline & 2010 & $209.3 \pm 13.1$ & 6.3 & $182.0 \pm 8.6$ & 4.7 \\
\hline & 2011 & $193.7 \pm 26.1$ & 8.3 & $154.2 \pm 10.3$ & 6.7 \\
\hline
\end{tabular}

Table 3. Differences in timings of the transition from earlywood to latewood and early phloem to late phloem as evaluated using mixed linear models in which 'year' was the repeated factor and 'site' was the fixed factor. Bold values are significant at a 0.05 level.

\begin{tabular}{ccccc}
\hline & \multicolumn{2}{c}{$\begin{array}{c}\text { Transition from Earlywood to } \\
\text { Latewood }\end{array}$} & \multicolumn{2}{c}{$\begin{array}{c}\text { Transition from Early Phloem to } \\
\text { Late Phloem }\end{array}$} \\
\cline { 2 - 5 } & F & $p$ & F & $p$ \\
\hline Site (S) & 4.499 & $\mathbf{0 . 0 2 9 4}$ & $\mathbf{7 5 . 1 5 9}$ & $\mathbf{0 . 0 0 0}$ \\
Year (Y) & 1.693 & 0.2127 & $\mathbf{6 . 5 7 8}$ & $\mathbf{0 . 0 2 1}$ \\
S $\times$ Y & 1.559 & 0.2424 & 1.904 & 0.183 \\
\hline
\end{tabular}

\subsection{Sensitivity Analysis for Xylem Increment}

Sensitivity analysis was used to evaluate the individual contributions $d_{E}$ and $r_{m}$ to the total number of xylem $\left(n_{X C}\right)$, earlywood $\left(n_{E X C}\right)$, and latewood $\left(n_{L X C}\right)$ cells formed during the growing season. When the mean value of $r_{m}$ was kept constant and $d_{E}$ could vary within a range of two standard deviations of its mean, the resulting $n_{X C}$ varied from 27 to 59 cells, with a range of variation of 32 cells (Figure 2, Table 4). In contrast, when $d_{E}$ was kept constant to its mean value and rm could vary within two standard deviations of its mean, $n_{X C}$ varied from 10 to 77 cells, with a range of variation of 67 cells. The sensitivity analysis therefore estimated the average effects of $r_{m}$ and $d_{E}$ as $68 \%$ and $32 \%$, respectively. The analysis showed that $n_{\mathrm{XC}}$ was substantially more sensitive to $r_{m}$ and only marginally sensitive to $d_{E}$. The duration of earlywood formation was on average 35 days longer compared to latewood formation. Sensitivity analysis showed that $d_{E}$ and $r_{m}$ had different contributions to the widths of earlywood and latewood. While in earlywood, $r_{m}$ contributed $55 \%$ to the total cell number, the contribution of $d_{E}$ was higher in latewood (57\%) (Table 4). 

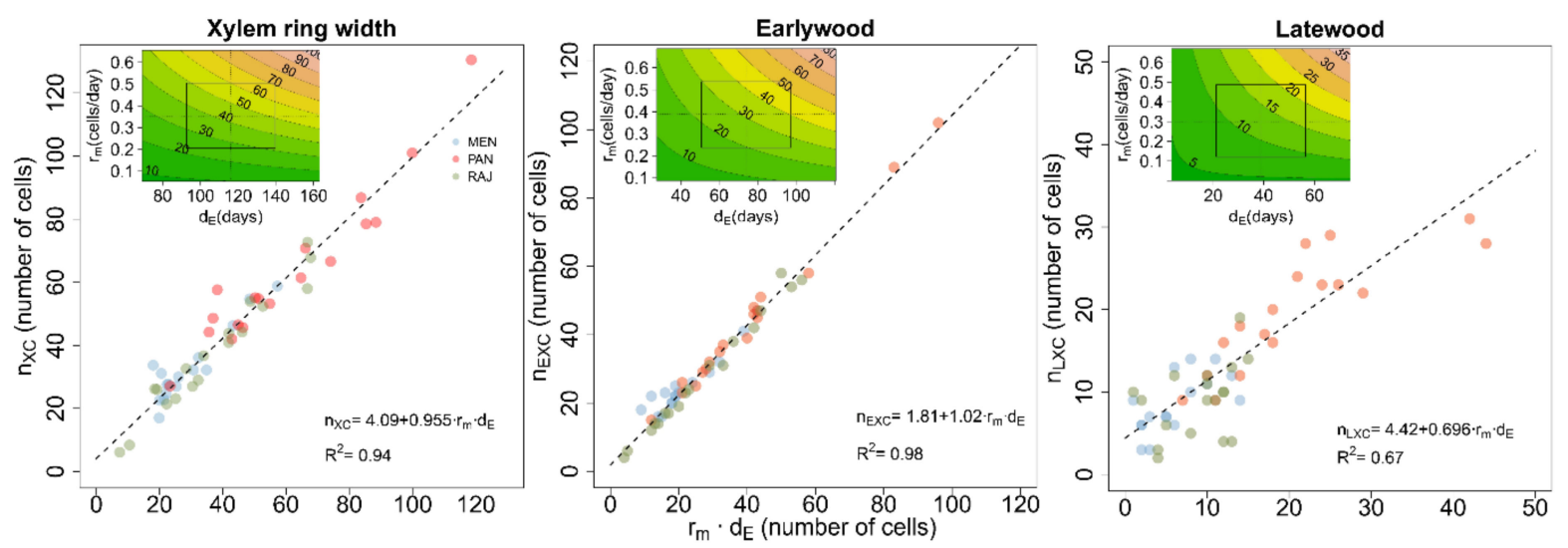

Figure 2. Simple physical model of the total number of xylem cells $\left(n_{X C}\right)$, number of earlywood cells ( $\left.n_{E X C}\right)$, number of latewood cells $\left(n_{L X C}\right)$, and the average rate $\left(r_{m}\right)$ and duration $\left(d_{E}\right)$ of production of these cell types in Norway spruce. The dashed line represents the regression. Sensitivity analysis of the physical model for the widths of xylem ring, earlywood, and latewood. The dashed lines represent the means, and the frame delimits the area of the mean \pm standard deviation.

Table 4. Results of sensitivity analysis for the widths of xylem ring, earlywood and latewood expressed in number of cells. $d_{E}$-duration of cell production; $r_{m}$-rate of cell production; SDstandard deviation; $n_{X C}-$ number of xylem cells; $n_{E X C}$-number of earlywood cells; $n_{L X C}$-number of latewood cells.

\begin{tabular}{cccc}
\hline & & Mean \pm SD & Contribution to $n_{\boldsymbol{X C}}$ \\
\hline \multirow{2}{*}{ Xylem ring } & $d_{E}$ (days) & $116.2 \pm 23.5$ & $32 \%$ \\
& $r_{m}$ (cells/day) & $0.35 \pm 0.15$ & $68 \%$ \\
\hline \multirow{2}{*}{ Earlywood } & $d_{E}$ (days) & $74.1 \pm 23.3$ & $45 \%$ \\
& $r_{m}$ (cells/day) & $0.39 \pm 0.15$ & $55 \%$ \\
\hline \multirow{2}{*}{ Latewood } & $d_{E}$ (days) & $38.9 \pm 17.7$ & $57 \%$ \\
& $r_{m}$ (cells/day) & $0.30 \pm 0.18$ & $43 \%$ \\
\hline
\end{tabular}

\subsection{Sensitivity Analysis for Phloem Increment}

The duration of phloem growth ring formation was estimated to be 24.6 days longer than that of xylem formation (Tables 4 and 5) due to the onset of early phloem development prior to cambium reactivation. Sensitivity analysis showed that rm contributed $59 \%$ and $68 \%$ of the changes in the total number of phloem and xylem cells, respectively (Figure 3, Table 5). The duration of early phloem formation was much shorter (48 days) than that of late phloem formation. At all sites, the number of cells in early phloem $\left(n_{E P C}\right)$ varied between three and five layers, while the number of late phloem cells $\left(n_{E P C}\right)$ varied between 2 and 12 layers. For the total number of phloem cells $\left(n_{P C}\right)$ and for the number of late phloem cells $\left(n_{L P C}\right)$, the model showed a significant relationship with $r_{m}{ }^{*} d_{E}$, while for early phloem the relationship was not significant. Sensitivity analysis for late phloem showed similar results as in the case of total phloem cell number; $d_{E}$ contributed $53 \%$ and $r_{m} 47 \%$ to the number of late phloem cells.

Table 5. Results of sensitivity analysis for the widths of phloem ring, early phloem and late phloem expressed in number of cells. $d_{E}$-duration of cell production; $r_{m}$-rate of cell production; SDstandard deviation; $n_{P C}-$ number of phloem cells; $n_{L P C}$-number of late phloem cells.

\begin{tabular}{cccc}
\hline & & Mean \pm SD & Contribution to $\boldsymbol{n}_{\boldsymbol{P C}}$ \\
\hline \multirow{2}{*}{ Phloem ring } & $d_{E}$ (days) & $140.8 \pm 24.6$ & $41 \%$ \\
& $r_{m}$ (cells/day) & $0.06 \pm 0.01$ & $59 \%$ \\
\hline \multirow{2}{*}{ Late phloem } & $d_{E}$ (days) & $95.9 \pm 26.6$ & $47 \%$ \\
& $r_{m}$ (cells/day) & $0.06 \pm 0.02$ & $53 \%$ \\
\hline
\end{tabular}



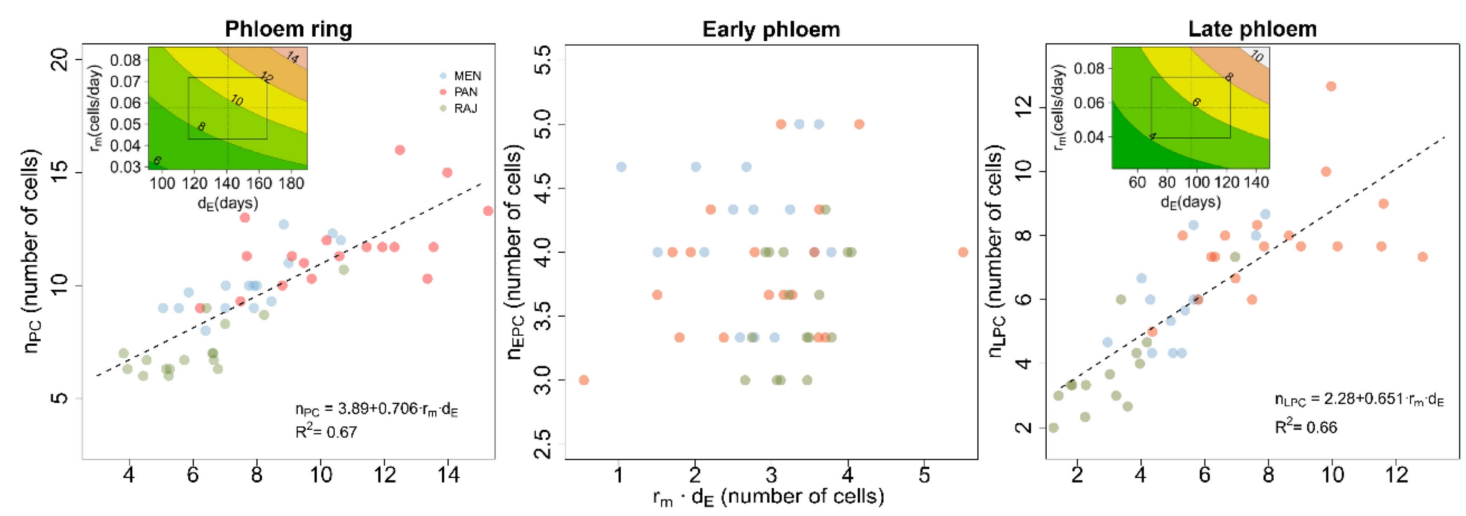

Figure 3. Simple physical model of the total number of phloem cells $\left(n_{P C}\right)$ number of early phloem cells $\left(n_{E P C}\right)$ number of late phloem cells $\left(n_{L P C}\right)$, and the average rate $\left(r_{m}\right)$ and duration $\left(d_{E}\right)$ of production of these type of cells in Norway spruce. There was no significant relationship between number of early phloem cells $\left(n_{E P C}\right)$ and $r_{m}{ }^{*} d_{E}$. The dashed line represents the regression. Sensitivity analysis of the physical model for the widths of phloem ring and late phloem. The dashed lines represent the means, and the frame delimits the area of the mean \pm standard deviation.

\section{Discussion}

In the present study, we only partially confirmed our first hypothesis (H1), that the transition dates are fairly site-specific and less variable between growth seasons, especially in phloem. We found significant differences in the transition dates from earlywood to latewood between the selected sites but not between the growth seasons in trees from the same site. Contrary to our expectations, we also found differences in the transition date from early phloem to late phloem between the analysed growth seasons. The findings are in line with previously observed site-specific patterns of cambial phenology, which is reflected in various wood and phloem anatomies $[17,18]$. The second hypothesis $(\mathrm{H} 2)$, on a close link between the onset of cambial cell production and the transition dates was rejected.

\subsection{Transition from Earlywood to Latewood}

The relationship between tree-ring width and earlywood/latewood portions depends on site, age, and species specifics. A negative relationship between ring width and latewood proportion is typically found in wood of conifers [27]. A higher proportion of earlywood is thus found in wider rings; this negatively affects wood density and, ultimately, wood properties [7]. However, these relations are quite complex and non-linear because of the nonhomogeneous structure of earlywood and latewood, which may change in response to various internal (genes, hormones) and external (abiotic, biotic) stimuli $[5,28,29]$.

In this study, the transition date from earlywood-to-latewood was similar at the two Slovenian sites, at the beginning of July, while at RAJ it occurred two weeks later. Although xylem increments were the widest at low elevation site PAN, the earlywood proportion was the highest at MEN, which contradicts the above-mentioned relationship between xylem ring width and earlywood proportion. Interestingly the transition date did not necessarily affect the proportion of earlywood and latewood, neither at the same site nor between the sites. No trend between the transition date and elevation was also recently reported by [30]. It was suggested that photoperiod also has a major impact on cell characteristics, in particular on latewood [23].

We found that the duration of earlywood formation was generally longer than that of latewood formation. The number of earlywood and latewood cells was comparable at PAN and RAJ, while at MEN the share of earlywood cells was higher [18]. Sensitivity analysis showed that in the case of earlywood, the rate of cell production contributed $55 \%$ to the total cell number, while in the case of latewood, the contribution of duration was higher (57\%). The final annual xylem increment is thus the result of the duration and rate of cambial cell production [17], whereas the xylem structure-i.e., tracheid features along the ring, depends on kinetics and the interaction of wood formation processes (expansion 
and wall formation). Cuny et al. [14] reported that the duration of cell enlargement was the main driver of cell size and wall thickness, contributing $56 \%$ of wood density variation along the rings in three temperate conifer species. Their new approach and developed mechanistic model of wood formation kinetics, which determines the wood structure in conifers, is an important step towards better understanding the climate-growth relationship in tree species from contrasting environments, including extreme events, which may give rise to peculiar patterns of xylogenesis, often triggering altered wood structure, such as intra-annual density fluctuations [31].

Differences in tracheid characteristics found in our previous study mainly occurred in latewood and were partly related to local climatic characteristics [18]. Similar findings were shown by some other research groups and were ascribed to the hydraulic adaptation mechanisms of trees to specific site conditions [11]. However, other research groups have found strong climatic control and latitudinal effects on earlywood production in various conifer species in colder and boreal regions [7,32], which could be ascribed to the abovementioned site and tree differences. In addition to climatic conditions, tree and crown size are important determinants of cell characteristics [33], and the plasticity of secondary growth has been shown to allow trees to adapt the structure of vascular tissues to function optimally under local environmental conditions [34].

Weather conditions prior to, and especially during, radial growth affect cambial activity and cell development patterns, such as cell expansion and secondary cell wall synthesis [35]. They also determine the amount and properties of wood [36]. In terms of conductivity, they influence the hydraulic efficiency and cavitation vulnerability of tracheids. Wood formation and anatomy data are very valuable because they allow a detailed assessment of xylem structure and the dependence of radial growth on local conditions. Since xylogenesis data are usually available only over a limited period and only few laboratories have records covering more than 10 years, long-term and high-resolution analysis of xylem anatomy has proved to be a promising approach in extending wood formation data [9]. This information will improve our mechanistic understanding of environmental impacts on radial growth of trees and, ultimately, future tree performance.

Site, species, and age-specific radial growth sensitivity to climatic conditions have already been previously reported [37]. Norway spruce from temperate forests, for example, is known to respond less intensely to moderate climatic variations than trees from more extreme environments, where temperature or water availability are the primary limiting factors of growth processes [38,39]. Tree competition, tree vitality, and forest management practices at optimal forest sites may have a major impact on radial growth [39]. The growth specifics of trees from various environments may thus be governed by different factors, which should be considered in comparative studies.

The variation of tracheid lumen size and wall thickness across the annual ring defines wood properties [10]. For an assessment of the hydraulic properties of a tree in relation to its performance, the annual width of xylem increment and detailed cell characteristicsincluding their length and pit structure-should be considered [40]. In addition, an annual xylem increment should be adjusted to its relative hydraulic contribution to the whole sapwood area [41]. Finally, it should be noted that local site conditions-such as fine-scale topography, soil properties, and rock type-may also affect tree growth patterns and wood structure [39].

\subsection{Transition from Early Phloem to Late Phloem}

The transition date from early phloem to late phloem differed between the study sites and growth seasons. Previously, we found that phloem increment width was not associated with elevation; it was widest at PAN and narrowest at RAJ [18]. However, transition dates were negatively related to phloem width; they occurred earliest at PAN and latest at RAJ. This finding is interesting because the structure of early phloem is generally stable and usually consists of 3-4(5) layers of early phloem sieve cells. In addition, the transition dates were not related to the onset of cambial productivity; they occurred 2-3.5 weeks and 
5.5-3.5 after the onset of cell division at PAN and RAJ, respectively. It can be concluded that the dynamics of sieve cell formation differed between the sites, being the longest at RAJ and the shortest at PAN. Our results suggest that there are no significant relationships between the stable number of early phloem cells and rate and duration of their formation. This lack of a clear link may be partly explained by the fact that the initial early phloem part (1-2 cell layers) consist of overwintering cells. These cells are formed by the cambium at the end of the previous growing season; they then overwinter and start to differentiate in the following spring, prior to the onset of cambial productivity [25].

The structure and width of late phloem were much more variable and were closely related to the ring width, which is in line with previous reports [18]. While at PAN and MEN early phloem constituted more than $50 \%$ of the phloem increment, at RAJ the proportion of early and late phloem was either comparable in rings of about 8 cell layers wide (2009) or early phloem predominated in rings composed of fewer than 7 cell layers (2010 and 2011).

With few exceptions, phloem formation has generally been much less investigated than xylem formation. However, of all European tree species, most of the existing phloem formation data on phloem formation has been conducted on Norway spruce $[17,25,30,42]$. Even less is known about the timing of transition from early phloem to late phloem. Miller et al. [30] recently compared the transition dates in Norway spruce at different elevations and found a significant trend along the gradient; they occurred later at higher elevations. The study concluded that the timing of transition depends on numerous factors, such as the onset of cambial productivity, rate of cell production, and number of cells in early phloem.

\subsection{Characteristics of Early Phloem and Late Phloem}

There are two main long-distance pathways in trees, the first refers to the xylem conduits, which transport water and nutrients taken up by the roots to the leaves to maintain evapotranspiration and photosynthesis, and the second refers to the phloem, which delivers signaling molecules and photosynthates, necessary for respiration and growth to developing tissues [43]. The xylem and phloem are closely linked both spatially and functionally [16]; therefore, carbon gain and tree viability depend on the functioning and interaction of these two vascular tissues [44].

Unlike tracheids in spruce wood, phloem sieve cells function for only one to two growing seasons, after which the cells die and collapse [45]. Therefore, rapid development of the initial early phloem sieve cells in spring is necessary, as the survival of a tree depends on the annual formation of the phloem increment to maintain the above-mentioned functions [16]. As with xylem, early phloem and late phloem structurally differ in temperate tree species, and consequently differ their main roles in a tree. The main function of the early phloem characterized by large sieve cells is conduction [16]. The late phloem consists of narrow sieve cells and axial parenchyma, indicating the prevailing storage function. At the transition from early phloem to late phloem is a tangential band of axial parenchyma, and in wider increments, a second, discontinuous tangential band of axial parenchyma forms in late phloem [25]. Ray and axial parenchyma network store carbohydrates, other metabolites, and water reserves [46]. Thus, a trade-off between conducting (sieve cells) and storing (axial parenchyma) functions is influenced by the proportions of early phloem and late phloem. Since the structure of early phloem is more stable than that of late phloem, the former is considered to be less affected by site conditions because of its greater importance to tree survival [5]. However, a reduction of late phloem can significantly reduce the amount of axial parenchyma, which, in turn, can lead to greater tree susceptibility to drought or pathogens $[47,48]$. Recent studies show that parenchyma provides a metabolic and energetic link between mature xylem and phloem [49]; thus, more detailed studies are needed to better understand the role of parenchyma cells in the overall functioning of trees in different environments. 


\subsection{Site-Specifics}

As already mentioned, local site conditions and the plasticity of secondary growth to adapt to such conditions are key factors in explaining differences in xylem and phloem anatomy between the three temperate sites. In addition to altitudinal and latitudinal differences, the amount and distribution of precipitation also differ between the sites, especially between those in Slovenia and the Czech Republic one. Even though none of the sites was precipitation limited, $55 \%$ and $62 \%$ less rainfall was recorded at RAJ compared to PAN and MEN, respectively, in the period 2009-2011. In addition, at RAJ, the majority of rain falls predominantly during the growing period. Drought events at RAJ are very likely to occur, as for instance in 2011, when $60 \%$ less precipitation was recorded in the first half of the year than in the previous year [50]. However, this did not negatively affect radial increments in Norway spruce [18], while in common beech, the xylem increments were $40 \%$ narrower in 2011 [50]. These differences can be ascribed to site specifics (Slovenian and Czech sites), particularly soil properties, and to species specifics (Norway spruce and common beech). Thus, the amount of precipitation is not a direct indicator of water shortage in a tree; soil properties, which are not considered in this study, may also greatly affect water availability.

\subsection{Genetic Control of Radial Growth}

Our results indicate a high intra-specific plasticity of the studied phenological patterns in spruce. However, it should be emphasized that genes also have an important influence on the phenological events, as already previously demonstrated [51,52]. In addition, seed origin is known to influence tree growth characteristics and their response to local environmental conditions $[53,54]$. Due to the long history of planting and provenance transfers, spruce in Central Europe is reported to have lower genetic diversity compared to Eastern and Northern Europe, which is reflected in less pronounced regional variation patterns [55]. As spruce was intensively sawn/planted with seeds/seedlings of unknown origin at all our sites [56,57], it is not possible to assess the relative contribution of genetic determination, epigenetic regulation, and somatic adaptation to growth and development processes. Established provenance experiments [58] would therefore be the most appropriate choice for further research in this direction.

\section{Conclusions}

The phloem phenology and structure are generally less known; thus, this part of the analysis substantially complements the information on radial growth of trees, consisting of wood and phloem components. Despite the increasing interest in wood formation studies, the timing of the transition dates from earlywood to latewood has been less investigated. Therefore, the results of the current study are important to better understand the yearto-year variability of this phenological event in Norway spruce from three contrasting temperate sites, also in relation to cambial phenology. Differences in the transition dates are reflected in wood anatomy, which can be attributed to the hydraulic adaptation of trees to specific site conditions. The shown plasticity of secondary growth allows trees to adapt the structure of xylem and phloem to function optimally under local environmental conditions. Thus, long-term data on seasonal xylem and phloem formation patterns and structure will improve our understanding of the process-based response of trees to climate-phenologyrelated changes and, ultimately, on their future success and performance in different environments. From an economic perspective, changes in wood structure will affect wood density and consequently wood properties (timber quality), which is an important issue for forest-based industry.

Author Contributions: Conceptualization, J.G. and P.P.; Methodology, J.G., P.P., and M.d.L.; Validation, H.V. and K.E.; Formal analysis, H.V., V.G., J.G., K.Č., K.E., and P.P.; Investigation, H.V., V.G., J.G., K.C.., and P.P.; Writing—original draft preparation, J.G. and P.P.; Writing—review and editing, all; Visualization, P.P.; Funding acquisition, all. All authors have read and agreed to the published version of the manuscript. 
Funding: This research was funded by the Slovenian Research Agency, through research core funding nos. P4-0107, P4-0015, P4-0085 and projects V4-2017, J4-2541 V4-1419, and Z4-7318. The study was funded also by the Spanish Science and Innovation Ministry (MICINN), the ELENA program (CGL2012-31668), by the FEDER program of the European Union and by the European Social Fund and the state budget of the Czech Republic, Project Indicators of Trees Vitality Reg. No. CZ.1.07/2.3.00/20.0265.

Institutional Review Board Statement: Not applicable.

Informed Consent Statement: Not applicable.

Data Availability Statement: The data presented in this study are available in the article. Additional data are available on request from the corresponding author.

Acknowledgments: The authors gratefully acknowledge the help of Marko Beber and the Slovenian Forest Service, Milko Detmar and Metropolitana d.o.o., as well as Luka Krže, Maks Merela, Marko Željko, Gabriela Vichrová, Jaroslav Kratochvíl, and Tomáš Kratochvíl for their immense help in the field and in the laboratory. We thank Martin Cregeen for language editing. The long-term climatic data for Rájec-Němčice site were provided by the Czech Hydrometeorological Institute. We thank the reviewers and academic editor for their valuable comments and suggestions, which improved the quality of the paper.

Conflicts of Interest: The authors declare no conflict of interest. The funders had no role in the design of the study; in the collection, analysis, or interpretation of the data; in the writing of the manuscript, or in the decision to publish the results.

\section{References}

1. Rossi, S.; Anfodillo, T.; Čufar, K.; Cuny, H.E.; Deslauriers, A.; Fonti, P.; Frank, D.; Gričar, J.; Gruber, A.; King, G.M.; et al. A meta-analysis of cambium phenology and growth: Linear and non-linear patterns in conifers of the northern hemisphere. Ann. Bot. 2013, 112, 1911-1920. [CrossRef]

2. Prislan, P.; Gričar, J.; Čufar, K.; de Luis, M.; Merela, M.; Rossi, S. Growing season and radial growth predicted for Fagus sylvatica under climate change. Clim. Chang. 2019, 153, 181-197. [CrossRef]

3. Rathgeber, C.B.K.; Rossi, S.; Bontemps, J.-D. Cambial activity related to tree size in a mature silver-fir plantation. Ann. Bot. 2011, 108, 429-438. [CrossRef]

4. Cuny, H.E.; Rathgeber, C.B.K.; Lebourgeois, F.; Fortin, M.; Fournier, M. Life strategies in intra-annual dynamics of wood formation: Example of three conifer species in a temperate forest in north-east France. Tree Physiol. 2012, 32, 612-625. [CrossRef]

5. Larson, P.R. The Vascular Cambium: Development and Structure; Springer-Verlag: New York, NY, USA, 1994.

6. Rossi, S.; Deslauriers, A.; Anfodillo, T.; Carrer, M. Age-dependent xylogenesis in timberline conifers. New Phytol. 2008, 177, 199-208.

7. Zhang, S.; Belien, E.; Ren, H.; Rossi, S.; Huang, J. Wood anatomy of boreal species in a warming world: A review. Iforest Biogeosciences For. 2020, 13, 130-138. [CrossRef]

8. von Arx, G.; Carrer, M. ROXAS-A new tool to build centuries-long tracheid-lumen chronologies in conifers. Dendrochronologia 2014, 32, 290-293. [CrossRef]

9. Castagneri, D.; Fonti, P.; von Arx, G.; Carrer, M. How does climate influence xylem morphogenesis over the growing season? Insights from long-term intra-ring anatomy in Picea abies. Ann. Bot. 2017, 119, 1011-1020. [CrossRef]

10. Fonti, P.; von Arx, G.; García-González, I.; Eilmann, B.; Sass-Klaassen, U.; Gärtner, H.; Eckstein, D. Studying global change through investigation of the plastic responses of xylem anatomy in tree rings. New Phytol. 2010, 185, 42-53. [CrossRef]

11. Park, Y.-I.; Spiecker, H. Variations in the tree-ring structure of Norway spruce (Picea abies) under contrasting climates. Dendrochronologia 2005, 23, 93-104. [CrossRef]

12. Prendin, A.L.; Mayr, S.; Beikircher, B.; von Arx, G.; Petit, G. Xylem anatomical adjustments prioritize hydraulic efficiency over safety as Norway spruce trees grow taller. Tree Physiol. 2018, 38, 1088-1097. [CrossRef]

13. Ziaco, E.; Truettner, C.; Biondi, F.; Bullock, S. Moisture-driven xylogenesis in Pinus ponderosa from a Mojave Desert mountain reveals high phenological plasticity. Plant Cell Env. 2018, 41, 823-836. [CrossRef]

14. Cuny, H.E.; Rathgeber, C.B.K.; Frank, D.; Fonti, P.; Fournier, M. Kinetics of tracheid development explain conifer tree-ring structure. New Phytol. 2014, 203, 1231-1241. [CrossRef]

15. Denne, M.P. Definition of latewood according to Mork (1928). IAWA J. 1988, 10, 59-61.

16. Evert, R.F. Esau's Plant Anatomy Meristems, Cells, and Tissues of the Plant Body: Their Structure, Function, and Development, 3rd ed.; John Wiley \& Sons, Inc.: Hoboken, NJ, USA, 2006.

17. Gričar, J.; Prislan, P.; Gryc, V.; Vavrčík, H.; de Luis, M.; Čufar, K. Plastic and locally adapted phenology in cambial seasonality and production of xylem and phloem cells in Picea abies from temperate environments. Tree Physiol. 2014, 34, 869-881. [CrossRef]

18. Gricar, J.; Prislan, P.; De Luis, M.; Gryc, V.; Hacurova, J.; Vavrcik, H.; Cufar, K. Plasticity in variation of xylem and phloem cell characteristics of Norway spruce under different local conditions. Front. Plant Sci. 2015, 6, 730. [CrossRef] 
19. Balducci, L.; Cuny, H.E.; Rathgeber, C.B.; Deslauriers, A.; Giovannelli, A.; Rossi, S. Compensatory mechanisms mitigate the effect of warming and drought on wood formation. Plant Cell Env. 2016, 39, 1338-1352. [CrossRef]

20. Fabiánek, T.; Menšík, L.; Tomášková, I.; Kulhavý, J. Effects of spruce, beech and mixed commercial stand on humus conditions of forest soils. J. For. Sci. 2009, 55, 119-126.

21. Rossi, S.; Anfodillo, T.; Menardi, R. Trephor: A new tool for sampling microcores from tree stems. IAWA J. 2006, $27,89-97$.

22. Cuny, H.E.; Rathgeber, C.B.K.; Kiessé, T.S.; Hartmann, F.P.; Barbeito, I.; Fournier, M. Generalized additive models reveal the intrinsic complexity of wood formation dynamics. J. Exp. Bot. 2013, 64, 1983-1994. [CrossRef]

23. Cuny, H.E.; Rathgeber, C.B.K.; Frank, D.; Fonti, P.; Mäkinen, H.; Prislan, P.; Rossi, S.; del Castillo, E.M.; Campelo, F.; Vavrčík, H.; et al. Woody biomass production lags stem-girth increase by over one month in coniferous forests. Nat. Plants 2015, 1, 15160. Available online: http:/ / www.nature.com/articles/nplants2015160\#supplementary-information (accessed on 26 October 2015). [CrossRef]

24. R Core Team. R: A Language and Environment for Statistical Computing; R Foundation for Statistical Computing: Vienna, Austria, 2012.

25. Gričar, J.; Čufar, K. Seasonal dynamics of phloem and xylem formation in silver fir and Norway spruce as affected by drought. Russ. J. Plant Physiol. 2008, 55, 538-543.

26. Quinn, G.P.; Keough, M.J. Experimental design and data analysis for biologists, 1st ed.; Cambridge University Press: Cambridge, UK, 2002.

27. Dinwoodie, J.M. Timber, Its Nature and Behaviour; Van Nostrand Reinhold: New York, NY, USA, 1981.

28. Fonti, P.; Bryukhanova, M.V.; Myglan, V.S.; Kirdyanov, A.V.; Naumova, O.V.; Vaganov, E.A. Temperature-induced responses of xylem structure of Larix sibirica (Pinaceae) from the Russian Altay. Am. J. Bot. 2013, 100, 1332-1343. [CrossRef]

29. Zhirnova, D.F.; Belokopytova, L.V.; Babushkina, E.A.; Crivellaro, A.; Vaganov, E.A. Earlywood structure of evergreen conifers near forest line is habitat driven but latewood depends on species and seasons. Trees 2020. [CrossRef]

30. Miller, T.W.; Stangler, D.F.; Larysch, E.; Seifert, T.; Spiecker, H.; Kahle, H.-P. Plasticity of seasonal xylem and phloem production of Norway spruce along an elevational gradient. Trees 2020, 34, 1281-1297. [CrossRef]

31. Balzano, A.; Battipaglia, G.; Cherubini, P.; De Micco, V. Xylem Plasticity in Pinus pinaster and Quercus ilex growing at sites with different water availability in the Mediterranean region: Relations between intra-annual density fluctuations and environmental conditions. Forests 2020, 11, 379.

32. Huang, J.-G.; Bergeron, Y.; Zhai, L.; Denneler, B. Variation in intra-annual radial growth (xylem formation) of Picea mariana (Pinaceae) along a latitudinal gradient in western Quebec, Canada. Am. J. Bot. 2011, 98, 792-800. [CrossRef]

33. Rosell, J.A.; Olson, M.E.; Anfodillo, T. Scaling of xylem vessel diameter with plant size: Causes, predictions, and outstanding questions. Curr. For. Rep. 2017, 3, 46-59. [CrossRef]

34. De Kroon, H.; Huber, H.; Stuefer, J.F.; Van Groenendael, J.M. A modular concept of phenotypic plasticity in plants. New Phytol. 2005, 166, 73-82. [CrossRef]

35. Steppe, K.; Sterck, F.; Deslauriers, A. Diel growth dynamics in tree stems: Linking anatomy and ecophysiology. Trends Plant Sci 2015, 20, 335-343. [CrossRef]

36. Hölttä, T.; Mäkinen, H.; Nöjd, P.; Mäkelä, A.; Nikinmaa, E. A physiological model of softwood cambial growth. Tree Physiol. 2010, 30, 1235-1252. [CrossRef]

37. Carrer, M.; Motta, R.; Nola, P. Significant mean and extreme climate sensitivity of Norway spruce and silver fir at mid-elevation mesic sites in the Alps. PLoS ONE 2012, 7, e50755. [CrossRef]

38. Mäkinen, H.; Nöjd, P.; Kahle, H.-P.; Neumann, U.; Tveite, B.; Mielikäinen, K.; Röhle, H.; Spiecker, H. Large-scale climatic variability and radial increment variation of Picea abies (L.) Karst. in central and northern Europe. Trees 2003, 17, 173-184. [CrossRef]

39. Levanič, T.; Gričar, J.; Gagen, M.; Jalkanen, R.; Loader, N.; McCarroll, D.; Oven, P.; Robertson, I. The climate sensitivity of Norway spruce [Picea abies (L.) Karst.] in the southeastern European Alps. Trees 2009, 23, 169-180. [CrossRef]

40. Pittermann, J.; Sperry, J.S.; Hacke, U.G.; Wheeler, J.K.; Sikkema, E.H. Inter-tracheid pitting and the hydraulic efficiency of conifer wood: The role of tracheid allometry and cavitation protection. Am. J. Bot. 2006, 93, 1265-1273. [CrossRef]

41. Jyske, T.; Hölttä, T. Comparison of phloem and xylem hydraulic architecture in Picea abies stems. New Phytol. 2015, 205, 102-115. [CrossRef]

42. Swidrak, I.; Gruber, A.; Oberhuber, W. Xylem and phloem phenology in co-occurring conifers exposed to drought. Trees 2014, 28, 1161-1171. [CrossRef]

43. Petit, G.; Crivellaro, A. Comparative axial widening of phloem and xylem conduits in small woody plants. Trees 2014, $28,915-921$. [CrossRef]

44. Sevanto, S. Phloem transport and drought. J. Exp. Bot. 2014. [CrossRef]

45. Franceschi, V.R.; Krokene, P.; Krekling, T.; Christiansen, E. Phloem parenchyma cells are involved in local and distant defense responses to fungal inoculation or bark-beetle attack in Norway spruce (Pinaceae). Am. J. Bot. 2000, 87, 314-326.

46. Spicer, R. Symplasmic networks in secondary vascular tissues: Parenchyma distribution and activity supporting long-distance transport. J. Exp. Bot. 2014, 65, 1829-1848. [CrossRef]

47. Rosell, J.A.; Gleason, S.; Méndez-Alonzo, R.; Chang, Y.; Westoby, M. Bark functional ecology: Evidence for tradeoffs, functional coordination, and environment producing bark diversity. New Phytol. 2014, 201, 486-497. [CrossRef] 
48. Secchi, F.; Pagliarani, C.; Zwieniecki, M.A. The functional role of xylem parenchyma cells and aquaporins during recovery from severe water stress. Plant Cell Environ. 2017, 40, 858-871. [CrossRef]

49. Pfautsch, S.; Hölttä, T.; Mencuccini, M. Hydraulic functioning of tree stems-Fusing ray anatomy, radial transfer and capacitance. Tree Physiol. 2015, 35, 706-722. [CrossRef]

50. Giagli, K.; Gričar, J.; Vavrčík, H.; Menšík, L.; Gryc, V. The effects of drought on wood formation in Fagus sylvatica during two contrasting years. IAWA J. 2016, 37, 332-348. [CrossRef]

51. Jayawickrama, K.J.; McKeand, S.E.; Jett, J.B.; Wheeler, E.A. Date of earlywood-latewood transition in provenances and families of loblolly pine, and its relationship to growth phenology and juvenile wood specific gravity. Can. J. For. Res. 1997, 27, 1245-1253. [CrossRef]

52. Fukatsu, E.; Nakada, R. The timing of latewood formation determines the genetic variation of wood density in Larix kaempferi. Trees 2018, 32, 1233-1245. [CrossRef]

53. Oleksyn, J.; Modrzýnski, J.; Tjoelker, M.G.; Z·ytkowiak, R.; Reich, P.B.; Karolewski, P. Growth and physiology of Picea abies populations from elevational transects: Common garden evidence for altitudinal ecotypes and cold adaptation. Funct. Ecol. 1998, 12, 573-590. [CrossRef]

54. Johnsen, Ø.; Dæhlen, O.G.; Østreng, G.; Skrøppa, T. Daylength and temperature during seed production interactively affect adaptive performance of Picea abies progenies. New Phytol. 2005, 168, 589-596. [CrossRef]

55. Skrøppa, T. EUFORGEN Technical Guidelines for Genetic Conservation and Use for Norway Spruce (Picea abies); International Plant Genetic Resources Institute: Rome, Italy, 2003.

56. Nožička, J. Historical Evolution of Our Forests (Přehled Vývoje Našich Lesư); Státní zemědělské nakladatelství: Praha, Czech Republic, 1957.

57. Božič, G.; Konnert, M.; Zupančič, M.; Kraigher, H.; Kreft, I. Genetic differentiation of the indigenous Norway spruce (Picea abies (L.) Karst) populations in Slovenia investigated by means of isoenzyme gene markers. Zb. Gozdarstva Lesar. 2003, 71, 19-40.

58. Krutzsch, P. The IUFRO 1964/ 68 provenance test with Norway Spruce (Picea abies (L.) Karst.). Silvae Genet. 1974, $23,58-62$. 